\title{
МОНГОЛ ОРНЫ ЗАРИМ ЭМИЙН МӨӨГНИЙ ХИМИЙН НАЙРЛАГЫГ СУДАЛСАН ДУН
}

\author{
Ш.Наранмандах, Н.Дагийсүрэн \\ МУИС. Шинжлэх ухааны сургууль
}

\begin{abstract}
Хураангуй
СҮҮлийн жилүҮдэд монголчууд эмийн мөөгөөр бэлтгэсэн иайг ихээхэн хэрэглэх болсон тул тэдгээр мөөгний химийн найрлага, иим тэжээлийн бодисыг тогтоох зорилгоор хар модны агил Fотіtоріs officinalis (Vill. ex Fr.), хар модны туруyдай Fomitopsis pinicola (Schwarts. ex Fr.), хусны mуруyдай Fomes fomentarus (L. ex Fr.), хусны онгол Inonotus obliquиs (Pers. ex Fr.), хар модны тахай Laetiporus sulphureus (Bull. ex Fr.) зэрэг 5 зүйлийн эмийн мөөгний химийн найрлагын судалгааг гүйцэтгэж дүнг нэгтгэв. Судалгааны дүнд эдгээр мөөгүҮд нь уургийг 8.06-28.31\%, үл орлогдох амин хүчлийг 24.55$27.03 \%$, эслэгий $17.89-41.53 \%$, хитинийг 2.63-5.33\%, лигнинийг 2.69-5.42\%, нийт тосны агууламж 1.53-3.51\%, эрдэс элементийг 1.63-10.31\%-иар тус тус агуулдагийг тогтоов. Хар модны агил мөөг нь давирхайлаг бодис ихтэй (70\% хүртэл), чага нь усанд хандлагдах бодис ихтэй (39\%) мөөг болно.
\end{abstract}

Түлхүур үг: эмийн мөөг, уураг, амин хүчил, нүүрс-ус, эрдэс элемент, витамин

\section{ОРШИЛ}

Малгайт болон базидиомицет мөөг нь уурагт нэгдэл, үл орлогдох амин хүчил, эрдэс элемент, витамин, полисахаридыг ихээр агуулдаг [1]. Мөөг нь хялбар шингэдэг уургийн сайн эх үүсвэр бөгөөд уургийн агууламжаараа махнаас арай бага боловч үр тариа, хүнсний ногооноос илүү байдаг. Хүнсний мөөгний уургийн агууламж хуурай жингийнх нь10-40\% байх ба бүх үл орлогдох амин хүчлүүдийг агуулдаг [2]. Мөөгний нүүрс-усны агууламж, уурагтайгаа харьцуулбал бараг хоёр дахин бага байдаг ба үүгээрээ ногоон ургамлаас ялгаатай [3]. Мөөгний тос ханасан ба ханаагүй тосны хүчлийн харьцаа болон тосны хүчлийн бүрдлийн хувьд ургамлын тостой төсөөтэй болох нь тогтоогджээ [4]. Мөөг эрдэс бодисын агууламжаараа жимс жимсгэнэтэй бараг ойролцоо ажээ. Тухайн мөөгний төрөл зүйл, ургах орчноос хамаарч, мөөгөнд 4.21-11.57\% эрдэс бодис агуулагддаг байна $[3,4]$. Иймд мөөг хүнс тэжээлийн үнэт чанартай юм. Үүгээр зогсохгүй мөөг нь эмчилгээний өндөр ач холбогдолтой юм. Сүүлийн жилүүдэд мөөгний эмчилгээний чанарыг судлан тогтоох чиглэлийн судалгаа ихээр хийгдэж, мөөгнөөс олон тооны биологийн идэвхит бодисыг ялган авч судлаад байна [1].

Уламжлалт эмчилгээнд хэрэглэгдэж ирсэн, эмчилгээний өндөр үйлчлэлтэй бодисыг нийлэгжүүлдэг мөөгүүд байдаг боловч тэдгээрийг одоогийн байдлаар бүрэн судлаагүй байна. Иймд мөөгийг хүнс тэжээлийн талаас төдийгүй эмнэл зүйн болон эдийн засгийн үр ашиг сонирхлын үүднээс судлах шаардлагатай байгаа болно. Монгол оронд 400-аад зүйлийн мөөг ургадаг гэж үздэг хэдий ч тэдгээрийн биологийн идэвхит бодис болон химийн найрлагын судалгаa одоогоор хийгдээгүй 
байгаа тул бид эмчилгээний зорилгоор хэрэглэгддэг зарим мөөгний химийн найрлагыг тогтоосон судалгааны дүнг энд эмхэтгэв. Уламжлалт хэрэглээг нь үндэслэн, хар модны агил Fomitopis of- ficinalis, хар модны туруудай Fomitopsis pinicola, хусны туруудай Fomes fomentarus, хусны онгол Inonotus obliquus, хар модны тахиа Laetiporus sulphureus зэрэг 5 мөөгийг сонгон судласан болно.

\section{СУДАЛГААНЫ МАТЕРИАЛ БА АРГА ЗУЙ}

Судалгааны материал: Судалгаанд хар модны агил Fomitopis officinalis (Vill. ex Fr.), хар модны туруудай Fomitopsis pinicola (Schwarts. ex Fr.), хусны туруудай Fomes fomentarus (L. ex Fr.), хусны онгол Inonotus obliquus (Pers. ex Fr.), хар модны тахай Laetiporus sulphureus (Bull. еx Fr.) зэрэг 5 мөөгийг 2010 оны 8-p сард Сэлэнгэ аймгийн Ерөө сумын нутгаас түүж бэлтгэсэн ба мөөгүүдийн ангилал зүйн тодорхойлолтыг ШУА-ийн Ботаникийн хүрээлэнгийн эрдэм шинжилгээний ахлах ажилтан доктор Ч.Санчир хийсэн. Түүсэн мөөгийг жижиглэн сэрүүн, сүүдэр газарт дэлгэж хатаав.
Судалгааньл арга зүй: Уураг, азотат нэгдлийн агууламжийг Кельдалийн аргаар [5], уусдаг уургийн агууламжийг Лоурын аргаaр [6], амин хүчлийн бүрдлийг цаасны хроматографийн аргаар [5], энгийн нүүрс-усны агууламжийг Бертраны аргаaр [5], хитин, эслэгийг жингийн аргаaр [7], тос тосонцор бодисыг хий-шингэний хроматографийн аргаар [8], эрдэс элементийн агууламжийг рентгенфлоуресценци багажаар, аскорбины болон никотины хүчил, лигниний агууламжийг титрийн аргаар, каротиныг спектрофотометрийн аргаар [7] тус тус тодорхойлов.

\section{СУДАЛГААНЫ ҮР ДУН БА ХЭЛЭЛЦҮУЛЭГ}

Монгол оронд ургадаг 5 зүйлийн мөөгний уураг, азотот нэгдлийн агууламжийг тодорхойлсон дүнг хүснэгт 1-т нэгтгэв. Судалгааны дүнгээс $F$. fomentarus, F. pinicola ба L. sulphureus зэрэг эмийн мөөг нь уургийг хуурай жингийнхээ 20.79 - 28.31\% агуулдаг болох нь харагдаж байна. Энэ нь хүнсний мөөг уургийг хуурай жингийн 15.4 - 26.7\% [Yang ба бусад, 2001], 16.5 - 59.4\% [Kalac, 2009] агуулдаг гэсэн бусад судлаачдын дүнтэй ойролцоо байна. Иймд дээр дурдсан 3 зүйлийн ур мөөг ( $F$. fomentarus, F. pinicola ба L. sulphureus) нь хүнсний мөөгтэй ойролцоо хэмжээний уургийг агуулдаг, уургаар баялаг байна.

Эмийн ур мөөгний уураг, азотот нэгдлийн агууламж

Хүснэгт 1

(агаарын хуурай жинд агуулагдах хувиар)

\begin{tabular}{|c|c|c|c|c|c|}
\hline & Дээжний нэр & $\begin{array}{c}\text { Нийт азот, } \\
\%\end{array}$ & $\begin{array}{l}\text { Уургийн } \\
\text { азот, \% }\end{array}$ & $\begin{array}{c}\text { Нийт уураг, } \\
\%\end{array}$ & $\begin{array}{c}\text { Уусдаг уураг, } \\
\%\end{array}$ \\
\hline 1 & Fomitopsis officinalis & 1.36 & 1.09 & 6.84 & 6,0 \\
\hline 2 & Fomitopsis pinicola & 4.56 & 3.32 & 20.78 & 14.4 \\
\hline 3 & Fomes fomentarus & 5.20 & 4.52 & 28.31 & 24.4 \\
\hline 4 & Inonotus obliquus & 1.57 & 1.45 & 9.12 & 8.62 \\
\hline 5 & Laetiporus sulphureus & 5.37 & 3.93 & 24.59 & 11.36 \\
\hline 6 & Tricholoma mongolicum ${ }^{[18]}$ & 3,36 & 3,22 & 20,12 & 16,41 \\
\hline
\end{tabular}


Харин F. officinalis ба I. obliquus гэсэн 2 мөөг нь уураг бага (харгалзан 8.06\% $9.12 \%$ ) агуулдаг байна. Хэдийгээр уургийн агууламж бага байгаа ч нийт уургийн (98-99\%)-ийг хялбар хандлагддаг уураг бүрдүүлж байна. Энэ нь уг 2 мөөгний шим тэжээлийн чанарыг бууруулахгүй байж болох юм. Энэ 2 мөөгний уураг бага агуулж байгаа шалтгаан нь эдгээр мөөгүүд бага молекулт органик нэгдэл болон полисахаридыг ихээр агуулдагтай холбоотой. Тухайлбал, агил мөөг $F$. officinalis-ний хуурай жингийн 50аac илүҮ хувийг давирхайлаг бодис бүрдүүлдэг [Ремингтон ба бусад, 1918], мөн тритерпенойдын нэгдлээр баялаг [Андерсон, 1972] болох талаар материалууд байдаг. Чага мөөг I. obliquus 100 граммдаa $15.3 г р$-глюкан агуулдаг болохыг Реe нар (2008) тогтоосон байна.

5 зүйлийн эмийн ур мөөгний уургийн амин хүчлийн бүрдлийг цаасны хроматографийн аргаар судалсан дүнг Хүснэгт 2-т нэгтгэн харуулав. Судалгааны дүнгээс уургаар баялаг 3 зүйлийн мөөгүүд(F. fomentarus, F. pinicola and L. sulphureus)ийн нийт амин хүчлийн агууламж нь харгалзан 20.71гр/кг, 28.14 гр/кг ба 24.56 гр/кг байгаа ба нийт амин хүчилд эзлэх үл орлогдох амин хүчлийн агууламж нь $26.86 \%$ - 27.03\% байгаа нь харагдаж байна. Энэ нь Дэлхийн эрүүл мэндийн байгууллагын хүнсний бүтээгдэхүнд тавигдах шаардлага-[FAO/WHO,1989]-aас $\quad$ (35.0\%) арай доогуур байв. Харин үл орлогдох болон энгийн амин хүчлийн харьцаа нь 0.36-0.39 буюу (FAO/WHO,1989)-тай адил хэмжээнд байна.

Судалгаанд хамрагдсан мөөгний голлох амин хүчил нь аспарагины болон глутамины хүчил байгаа хүснэгт 2-оос харагдаж байна. Энэ нь хүнсний мөөгийн амин хүчлийг судалсан бусад судлаагчдынхтай (Бреене (1990), Маттила (2002) болон Луи ба бусад (2010)) адил байв. Мөн 5 зүйлийн ур мөөг нь хүхэр агуулсан амин хүчил болох цистейн, метионинийг хангалттай хэмжээгээр агуулж байв. Энэ нь хүнсний мөөгөнд агуулагддаг хэмжээнээс арай илүү Маттила ба Луи нарын дүнгээс ялгаатай байв. Үүний шалтгааныг ур мөөгний хүнсний мөөгнөөс ялгагдах үндсэн онцлог нь гэж үзлээ.

Мөөгүүдийн чөлөөт амин хүчлийн бүрдлийн судалгааны дүнг хүснэгт 3-т нэгтгэв. Хүснэгтээс модны ур мөөгүүдэд триптофан, фенилаланин, метионин өндөр агууламжтай байгаа нь харагдаж байна. 5 зүйлийн мөөгүүдээс L.sulphureus мөөг нь чөлөөт амин хүчлийн агууламжаараа бусдаасаа илүү байв. Түүний үл орлогдох ба энгийн амин хүчлийн харьцаа 0.50 болно.

Эмийн ур мөөгний уургийн амин хүчлийн бүрдэл

Хуснэгт 2 (агаарын хуурай жинд агуулагдах хувиар)

\begin{tabular}{|c|c|c|c|c|c|c|c|c|c|c|}
\hline \multirow{3}{*}{ Амин хүчлүүд } & \multicolumn{10}{|c|}{ Уургийн амин хүчлийн бүрдэл } \\
\hline & \multicolumn{2}{|c|}{$\begin{array}{l}\text { Fomitopsis of- } \\
\quad \text { ficinalis }\end{array}$} & \multicolumn{2}{|c|}{$\begin{array}{c}\text { Fomitopsis } \\
\text { pinicola }\end{array}$} & \multicolumn{2}{|c|}{$\begin{array}{l}\text { Fomes fomen- } \\
\text { tarus }\end{array}$} & \multicolumn{2}{|c|}{$\begin{array}{l}\text { Inonotus } \\
\text { obliquus }\end{array}$} & \multicolumn{2}{|c|}{$\begin{array}{l}\text { Laetiporus } \\
\text { sulphureus }\end{array}$} \\
\hline & $\Gamma / \kappa \Gamma$ & $\%^{a}$ & $\Gamma / \kappa \Gamma$ & $\%^{a}$ & $\Gamma / \kappa \Gamma$ & $\%^{a}$ & $\Gamma / \kappa \Gamma$ & $\%{ }^{a}$ & г/кг & $\%^{a}$ \\
\hline Аланин & 0.27 & 3.31 & 0.64 & 3.0 & 1.34 & 4.51 & 0.24 & 2.54 & 0.53 & 2.30 \\
\hline Аргинин & 0.36 & 4.40 & 0.52 & 2.43 & 1.08 & 3.63 & 0.39 & 4.13 & 1.11 & 4.35 \\
\hline Аспарагины хүчил & 1.99 & 23.75 & 4.52 & 21.01 & 6.81 & 22.78 & 2.27 & 23.84 & 5.20 & 20.37 \\
\hline Цистейн & 0.96 & 11.48 & 1.89 & 8.81 & 3.36 & 11.26 & 0.79 & 8.34 & 2.52 & 9.82 \\
\hline Глицин & 0.52 & 6.27 & 1.49 & 6.94 & 2.37 & 7.95 & 0.58 & 6.10 & 1.50 & 6.10 \\
\hline Глутамины хүчил & 0.98 & 11.75 & 4.03 & 18.76 & 3.34 & 11.19 & 1.18 & 12.40 & 3.90 & 15.32 \\
\hline Гистидин & 0.57 & 6.80 & 1.14 & 5.34 & 1.90 & 6.38 & 0.54 & 5.70 & 1.97 & 7.70 \\
\hline
\end{tabular}




\begin{tabular}{|c|c|c|c|c|c|c|c|c|c|c|}
\hline Серин & 0.19 & 2.29 & 0.34 & 1.59 & 0.20 & 0.68 & 0.34 & 3.65 & 0.75 & 2.95 \\
\hline Тирозин & 0.17 & 2.03 & 0.40 & 1.87 & 0.43 & 1.47 & 0.17 & 1.82 & 0.64 & 2.50 \\
\hline Пролин & ул мөр & ул мөр & $\begin{array}{c}\text { ул } \\
\text { мөр }\end{array}$ & $\begin{array}{c}\text { ул } \\
\text { мөр }\end{array}$ & $\begin{array}{c}\text { ул } \\
\text { мөр }\end{array}$ & $\begin{array}{c}\text { ул } \\
\text { мөр }\end{array}$ & $\begin{array}{c}\text { ул } \\
\text { мөр }\end{array}$ & $\begin{array}{c}\text { ул } \\
\text { мөр }\end{array}$ & $\begin{array}{c}\text { ул } \\
\text { мөр }\end{array}$ & $\begin{array}{c}\text { ул } \\
\text { мөр }\end{array}$ \\
\hline Лейцин \\
\hline Лизин
\end{tabular}

${ }^{e}$ үл орлогдох амин хүчил, \% ${ }^{a}$ - нийт амин хүчилд эзлэх хувь

Судалгааны дүнгээс уургаар баялаг 3 зүйлийн мөөгүүд- (F.fomentarus, F.pinicola and L.sulphureus)-ийн нийт амин хүчлийн агууламж нь харгалзан 20.71гр/кг, 28.14 гр/кг ба 24.56 гр/кг байгаа ба нийт амин хүчилд эзлэх үл орлогдох амин хүчлийн агууламж нь 26.86\% - 27.03\% байгаа нь харагдаж байна. Судалгаанд хамрагдсан мөөгний голлох амин хүчил нь аспарагины болон глутамины хүчил байгаа нь хүснэгт 2-оос харагдаж байна.

Мөөгүүдийн чөлөөт амин хүчлийн бүрдлийн судлахад модны ур мөөгүүдэд триптофан, фенил аланин, метионин өндөр агууламжтай байв. 5 зүйлийн мөөгүүдээс L.sulphureus мөөг нь чөлөөт амин хүчлийн агууламжаараа бусдаасаа илүү байв.

Эмийн ур мөөгний нүүрс-усны агууламжийг тодорхойлсон дүн Хүснэгт 3-ээс F.officinalis, L. sulphureus, I.obliquus мөөг нь эслэгийг 20\% хүртэл, F. pinicola $28 \%$ агуулж байхад $F$. fomentarus мөөг нь эслэг ихтэй (41.53\%) болох нь харагдаж байна. Мөөгүүд лигнинийг багаар буюу (2.7-5.4\%), хитинийг (2.63-5.33\%) агуулдаг байна. Модны ур мөөгүүд энгийн сахарыг багаар агуулдаг.

Эмийн ур мөөгний нүҮрс-усны агууламж (агаарын хуурай жинд агуулагдах хувиар)

\begin{tabular}{|c|c|c|c|c|c|c|}
\hline \multirow{2}{*}{\begin{tabular}{c} 
Мөөгний нэр \\
\cline { 2 - 7 }
\end{tabular}} & \multicolumn{3}{|c|}{$\begin{array}{c}\text { Нийлмэ нүүрс-усны } \\
\text { Ігуламж, \% }\end{array}$} & \multicolumn{3}{c|}{ Энгийн нүүрс-усны агууламж, мг\% } \\
\cline { 2 - 7 } & Эслэг & Хитин & Лигнин & $\begin{array}{c}\text { Ангижруулагч } \\
\text { сахар }\end{array}$ & Дисахар & Нийт сахар \\
\hline Fomitopsis officinalis & 17,89 & 5,32 & 2,69 & 164.47 & 38.11 & 204.59 \\
\hline Fomitopsis pinicola & 28,15 & 3,24 & 4,01 & 407,62 & 43,71 & 453,63 \\
\hline Fomes fomentarus & 41,53 & 2,63 & 5,42 & 187,64 & 92,12 & 284,65 \\
\hline Inonotus obliquus & 18,59 & 5,33 & 2,70 & 341.23 & 51.72 & 395.68 \\
\hline Laetiporus sulphureus & 18,83 & 5,26 & 3,35 & 339,73 & 232,61 & 584,64 \\
\hline
\end{tabular}

Эмийн ур мөөгний тосны агууламжийг тодорхойлсон дүнг хүснэгт 4-т нэгтгэв. 
Зарим модны ур мөөгний тосны хүчлийн бүрдэл

Хуснэгт 4

(агаарын хуурай жинд агуулагдах хувиар)

\begin{tabular}{|c|c|c|c|c|}
\hline Тосны хүчлийн бүрдэл, \% & $\begin{array}{l}\text { Inonotus } \\
\text { obliquus }\end{array}$ & $\begin{array}{c}\text { Fomes } \\
\text { fomentarius }\end{array}$ & $\begin{array}{c}\text { Fomitopsis } \\
\text { officinalis }\end{array}$ & $\begin{array}{l}\text { Laetiporus } \\
\text { sulphureus }\end{array}$ \\
\hline Нийт тосны агууламж, \% & 1.62 & 1.53 & 3.51 & 3.14 \\
\hline C14:1 & 0.01 & 0.01 & - & - \\
\hline C15:1 & 0.03 & 0.01 & 0.02 & 0.01 \\
\hline C16:1 & 0.01 & 0.14 & 0.08 & - \\
\hline $\mathrm{C} 17: 1$ & 0.02 & 0.01 & - & 0.77 \\
\hline $\mathrm{C} 18: 1 \mathrm{c}$ & 51.22 & 21.25 & 36.49 & 45.71 \\
\hline $\mathrm{C} 18: 2 \mathrm{n} 9 \mathrm{t}$ & 8.27 & 31.61 & 12.23 & 27.08 \\
\hline $\mathrm{C} 18: 2 \mathrm{n} 9 \mathrm{c}$ & 31.12 & 6.26 & 10.63 & 13.53 \\
\hline $\mathrm{C} 18: 3 \mathrm{n} 6$ & 2.52 & 16.56 & 14.52 & 1.90 \\
\hline $\mathrm{C} 18: 3 \mathrm{n} 3$ & 1.96 & 8.58 & 22.38 & 4.38 \\
\hline $\mathrm{C} 20: 3 \mathrm{n} 6$ & 0.17 & 1.41 & 0.49 & 1.32 \\
\hline $\mathrm{C} 20: 3 \mathrm{n} 3$ & 0.07 & - & 0.48 & 0.04 \\
\hline $\mathrm{C} 20: 4 \mathrm{n} 6$ & 0.32 & 0.64 & 0.42 & 1.06 \\
\hline $\mathrm{C} 20: 5 \mathrm{n} 3$ & 1.87 & 0.12 & 0.55 & 0.32 \\
\hline $\mathrm{C} 22: \ln 9$ & 0.19 & 0.01 & 0.13 & 0.23 \\
\hline $\mathrm{C} 22: 2$ & 0.03 & 2.10 & 0.24 & 0.43 \\
\hline Ханаагүй ТХ & 97.89 & 88.76 & 98.72 & 96.86 \\
\hline C15:0 & 0.01 & - & - & 0.01 \\
\hline C16:0 & 0.37 & 0.06 & - & 0.71 \\
\hline $\mathrm{C} 17: 0$ & 0.01 & - & - & 0.10 \\
\hline C18:0 & 1.10 & 7.12 & 0.18 & 1.22 \\
\hline $\mathrm{C} 20: 0$ & 0.20 & 0.34 & 0.26 & 0.61 \\
\hline $\mathrm{C} 21: 0$ & 0.27 & 0.36 & 0.21 & 0.09 \\
\hline C22:0 & - & 0.06 & 0.26 & 0.32 \\
\hline C23:0 & 0.09 & 3.25 & 0.32 & 0.03 \\
\hline Ханасан ТX & 2.08 & 11.22 & 1.26 & 3.13 \\
\hline
\end{tabular}

Судалгааны дүнгээс: F.officinalis, L.sulphureus 2 зүйлийн мөөг нь тосны агууламж өндөртэй (харгалзан 3.51 ба $3.14 \%$ ), I.obliquus, F.fomentarius 2 зүйлийн мөөг нь тосны агууламж багатай (харгалзан 1.62 ба $1.53 \%$ ) болох нь харагдаж байна. Судалгаанд хамрагдсан эмийн мөөгөнд ханаагүй эссенциал тосны хүчлүүд зонхилон агуулагддаг онцлогтой байна.

Мөөг эрдэс бодисоор нилээд баялаг бөгөөд агууламж нь жимс жимсгэнэтэй бараг ойролцоо гэж үздэг. Энэ судалгаагаар таван зүйлийн эмийн ур мөөгний эрдэс элементийн найрлагыг тогтоож, хүнсний мөөгтэй харьцуулан үнэлэлт өгөхийг зорилоо. 5 зүйлийн эмийн ур мөөгний хатаасан дээжийг шатаах зууханд $500^{\circ} \mathrm{C}$-т бүрэн шатаасны дараа эрдэс элементийн агууламжийг Японы NOBIRA, MESA500W маркийн рентгенфлюоресценцийн багажийг ашиглан тодорхойлсон. Мөөгүүдийн эрдэс элементийн судалгааны дүнг хүснэгт 5-д нэгтгэв. 
Эмийн ур мөөгний эрдэс элементийн агууламж

(агаарын хуурай жинд агуулагдах хувиар)

\begin{tabular}{|c|c|c|c|c|c|}
\hline Мөөгний нэр & $\begin{array}{c}\text { Fomitopsis } \\
\text { officinalis }\end{array}$ & $\begin{array}{c}\text { Fomitopsis } \\
\text { pinicola }\end{array}$ & $\begin{array}{c}\text { Fomes } \\
\text { fomentarus }\end{array}$ & $\begin{array}{c}\text { Inonotus } \\
\text { obliquus }\end{array}$ & $\begin{array}{c}\text { Laetiporus } \\
\text { sulphureus }\end{array}$ \\
\hline $\mathrm{YHc,} \mathrm{\%}$ & 10.31 & 1.63 & 3.22 & 5.41 & 7.96 \\
\hline $\mathrm{P}$ & 0.39 & 0.124 & 0.133 & 0.011 & 0.12 \\
\hline $\mathrm{S}$ & 0.141 & 0.022 & 0.039 & 0.008 & 0.033 \\
\hline $\mathrm{K}$ & 5.119 & 0.584 & 0.469 & 4.341 & 6.032 \\
\hline $\mathrm{Mg}$ & - & 0.208 & - & - & - \\
\hline $\mathrm{Ca}$ & 0.589 & 0.033 & 1.6 & - & 0.073 \\
\hline $\mathrm{Mn}$ & 0.092 & 0.013 & 0.001 & 0.039 & - \\
\hline $\mathrm{Fe}$ & 0.202 & 0.026 & 0.008 & - & 0.019 \\
\hline $\mathrm{Cu}$ & & 0.003 & 0.004 & 0.001 & 0.001 \\
\hline $\mathrm{Zn}$ & 0.566 & 0.043 & 0.022 & & 0.003 \\
\hline $\mathrm{AI}$ & 0.186 & 0.02 & 0.011 & 0.032 & 0.065 \\
\hline $\mathrm{Si}$ & 0.277 & 0.022 & & 0.011 & 0.035 \\
\hline $\mathrm{Sr}$ & - & - & 0.01 & - & - \\
\hline $\mathrm{Ba}$ & - & - & 0.003 & - & - \\
\hline
\end{tabular}

- Тухайн элемент агуулагдахгүй

Судалгааны дүнгээс харахад, хар модны агил F.officinalis нь бусад мөөгтэй харьцуулахад төмөр, хөнгөнцагаан, марганец, цайр, цахиур зэрэг элементийг 10-15 дахин ихээр агуулдаг, харин зэс, магнийг агуулдаггүй онцлогтой байна.

Хар модны туруудай F.pinicola мөөг нь калийн агууламжаар хэт бага $0.58 \%$ атлаа бусад ур мөөгөнд агуулагдахгүй магнийг $0.21 \%$ хүртэл, цайрыг $0.0431 \%$ буюу бусад хүнсний мөөгнөөс 10 дахин их агуулдаг онцлогтой болно. Хусны туруудай Ffomentarus зөвхөн Са-ийг бусад мөөгтэй харьцуулахад арай илүҮ агуулах боловч бусад элементийн агууламж бага байна. Хар модны агил F.officinalis, хар модны туруудай F.pinicola, хусны туруудай F.fomentarus зэрэг ур мөөгний нэг онцлог нь антиоксидант болон аллергийн эсрэг үйлчилгээтэй, гипофиз, бэлгийн булчирхайн үйл ажиллагааг эрчимжүүлдэг элемент болох цайрыг хүнсний мөөгнөөс олон дахин их агуулдагт оршино. Энэ нь тэдгээрийн эмчилгээний ач холбогдолтой байдгийн нэг баталгаа болно.

Мөөг нь холестрол агуулаагүй, илчлэг багатай төдийгүй дархлалын тогтолцоо, эр амьтны үржлийн тогтолцоонд чухал үүрэгтэй селен, ниациныг нилээд хэмжээгээр агуулдаг [Hobbs, 1995]. Бараг бүх хүнсний мөөгүүд А, $\mathrm{B}_{1}, \mathrm{~B}_{2}, \mathrm{C}, \mathrm{D}, \mathrm{PP}$ витаминыг ихээр агуулах бөгөөд эдгээр витамины агууламжаараа хүнсний ногоо, үр тарианаас их байдгийг тогтоосон байдаг [4]. Иймд эмийн 5 ур мөөгний витамин $\mathrm{C}$, $\mathrm{PP}$, каротин, органик хүчлийн хэмжээг тодорхойлсон судалгааны үр дүнг Хүснэгт 6-д харуулав. 
Эмийн ур мөөгний витамины агууламж

Хуснэгт 6

(агаарын хуурай жинд агуулагдах хувиар)

\begin{tabular}{|c|c|c|c|c|c|}
\hline Мөөгний нэр & Чийг, \% & $\begin{array}{c}\text { Витамин } \\
\text { С,мг \% }\end{array}$ & $\begin{array}{c}\text { Каротин, } \\
\text { мг \% }\end{array}$ & $\begin{array}{c}\text { Витамин РР, } \\
\text { мг \% }\end{array}$ & $\begin{array}{c}\text { Органик } \\
\text { хүчил, \% }\end{array}$ \\
\hline Fomitopsis officinalis & 5,8 & 115,4 & 0,18 & 74,7 & 4.5 \\
\hline Fomitopsis pinicola & 8,18 & 111,2 & 0,71 & 82,3 & 0.79 \\
\hline Fomes fomentarus & 13,8 & 111,2 & 0,14 & 64,6 & 0,77 \\
\hline Inonotus obliquus & 9,08 & 109,1 & 0,05 & 83,1 & 0,74 \\
\hline Laetiporus sulphureus & 12,59 & 112,3 & 0,25 & 72,6 & 0,70 \\
\hline
\end{tabular}

Хүснэгтээс эмийн ур мөөг нь витамин С болон витамин РР-ээр баялаг болох нь харагдаж байна. Мөөгүүдээс хар модны агил мөөг нь органик хүчлийг ихээр агуулдаг.
Эмийн ур мөөгний хандлагдах бодисыг тогтооход (Хүснэгт 7) F.officinalis -ийн ихэнх хэсэг буюу $72.42 \%$ нь спиртэнд хандлагдаж байв. Харин чага I.obliquus-ийн $39 \%$ нь усанд хандлагддаг байна.

Эмийн ур мөөгний хандлагдах бодис

Хуснэгт 7

\begin{tabular}{|c|c|c|c|}
\hline Мөөгний нэр & $\begin{array}{c}\text { Усанд хандлагдсан, } \\
\%\end{array}$ & $\begin{array}{c}\text { Спиртэнд хандлагдсан, } \\
\%\end{array}$ & $\begin{array}{c}\text { Гександ хандлагдсан, } \\
\%\end{array}$ \\
\hline Fomitopsis officinalis & 17,45 & 72.42 & 3.51 \\
\hline Fomitopsis pinicola & 18,10 & 27.56 & 2.34 \\
\hline Fomes fomentarus & 24,23 & 23.34 & 1.53 \\
\hline Inonotus obliquus & 39.00 & 20.67 & 1.62 \\
\hline Laetiporus sulphureus & 22.00 & 28.89 & 3.14 \\
\hline
\end{tabular}

\section{ДҮГНЭЛТ}

F.fomentarus, F.pinicola ба L.sulphureus зэрэг эмийн мөөг нь уургийг хуурай жингийнхээ 20.79 - 28.31\% агуулдаг уургаар баялаг байхад F.officinalis ба I.obliquus мөөг нь уураг бага (харгалзан $8.06 \% \quad 9.12 \%)$ агуулна. Судалгаанд хамрагдсан 5 зүйлийн ур мөөгүүдийн зонхилох амин хүчил нь аспарагины болон глутамины хүчил бөгөөд хүхэр агуулсан амин хүчил болох цистейн, метионинийг хүнсний мөөгөнд агуулагддаг хэмжээнээс илүү агуулдаг онцлогтой.

F.officinalis, L.sulphureus, I.obliquus мөөг нь эслэгийг 20\% хүртэл, F.pinicola 28\% агуулж байхад $F$. fomentarus мөөг нь эслэг ихтэй $(41.53 \%)$ Судалгаанд хамрагдсан 5 зүйлийн ур мөөгүүд лигнин (2.7-5.4\%), хитинийг (2.63-5.33\%) багаар агуулдаг.
Судалгаанд хамрагдсан 5 зүйлийн мөөгүүд ханаагүй эссенциал тосны хүчлээр баялаг ба үүнээс олейны хүчил (C18:1 cis) хамгийн өндөр агууламжтай байдаг онцлогтой.

Эмийн ур мөөг нь хүнсний мөөгтэй харьцуулахад эрдэс элементээр баялаг байгалийн үнэт түүхий эд болно. Эрдсийн агууламжаар хамгийн баялаг нь хар модны агил F.officinalis, харин эрдсийн агууламж багатай нь хар модны туруудай F.pinicola, хор хөнөөлтэй байж болзошгүй нь хусны туруудай F.fomentarus мөөг болохыг тогтоов.

Эмийн ур мөөгүүд витамин С болон витамин РР-ээр баялаг. 


\section{Ашигласан бүтээлийн жагсаалт}

1 Chang, S.T. (1996). Functional properties of edible mushrooms. Nutr. Rev 54(11), 91-93.

2 Breene, W.M. (1990) Nutritional and medicinal value of speciality mushrooms. Journal of Food Protection 53, 883-894.

3 Сержанина,Г.И., Яшкин,И.Я. (1986) Грибы, Минск,13-16

4 Под ред. Скурихина, И.М., Волгарева, М.Н. (1987) Химический состав пищевых продуктов. Справочник. Книга 2. М., Агропромиздат. 148-150. 160-162.

5 Плешков,Б.П. (1985). Практикум по биохимии растений. 123-129.

6 Lowry, O.H., Rosebrough, N.J., Farr, A.L., Randall, R.J. (1951). Protein measurement with the Folin phenol reagent. J.Biol.Chem. (193), 265-275.

7 Билай,В.И., Дудка.И.А и др. (1982) Методы экспериментальной микологий, 448-460.

8 Keits, M. (1975) Technica lipidologue. Moscow, 30-45.

9 Yang, JH., Lin, HC. \& Mau, JL. (2001) Non-volatile taste components of several speciality mushrooms, Food. Chem., 72: 465-471.

10 Kalac^, P. (2009) Chemical composition and nutritional value of European species of wild growing mushrooms: A review. Food. Chem., 113: 9-16.

11 Remington, J.P., Woods, H.C. \& others. (1918) The dispensatory of the United States of America. 20th edition. 39.

12 Anderson, C.G., and Epstein, W.W. (1971). Minor triterpenoids of Fomes officinalis. Phytochemistry, 10, 2713.

13 Rhee, S.J., Cho, S.Y., Kim, K.M., Cha, D.S. \& Park, H.J. (2008) A comparative study of analytical methods for alkali-soluble $\beta$-glucan in medicinal mushroom Chaga (Inonotus obliquus). LWT-Food Science and technology, 41(3)545-549.

14 FAO/WHO (1989) Protein quality evaluation. Report of the joint FAO/WHO expert consultation. Food and Agricultural organizations and the world health organization. Rome, Italy, Food. nut., p. 51.

15 Mattila, P., Salo-Vaananen, P., Konko, K., Aro, H., Jalava, T. (2002) Basic Composition and Amino acid Contents of Mushrooms Cultivated in Finland. J.Agric.Food Chem. 50. 64196422.

16 Lui, G., Wang, H., Zhou, B., Guo, X. \& Hu, X. (2010) Compositional analysis and nutritional studies of Tricholoma matsutake collected from Southwest China. Journal of Medicinal Plants Research Vol. 4(12).1222-1227.

17 Hobbs, H. (1995) Medicinal mushrooms. Amer.Bot.,87. 821-827.

18 Наранмандах,Ш. (2000) Талын цагаан мөөгний биохимийн бүрдэл, биологийн идэвхийн судалгаа. Докторын зэрэг горилсон бүтээл, 40-68. 


\title{
CHEMICAL COMPOSITIONS OF SOME MONGOLIAN MEDICINAL MUSHROOMS
}

\begin{abstract}
In Mongolia are growing many mushrooms, which are used in the traditional medicine. But their chemical compositions are not investigated up to now. Therefore in this study were determined chemical compositions and nutritional value of five mushrooms (Fomitopsis officinalis (Vill.ex.Fr.), Fomitopsis pinicola (Schwarts.ex.Fr.), Fomes fomentarus (L.ex.Fr.), Inonotus obliquus (Pers.ex.Fr.), Laetiporus sulphureus (Bull.ex.Fr.)) growing in Mongolia. The contents of crude protein, crude fat, carbohydrate, soluble sugars, ash, mineral elements and compositions of essential amino acids, fatty acids were analyzed.

The dried F.officinalis and I. obliquus contain very low crude protein $6.84 \%$ and $6.95 \%$, respectively. It was less than in edible mushrooms. The protein content of the other 3 species F. fomentarus, F. pinicola and L. sulphureus was in the range $20.79 \%-28.31 \%$ such as in most medicinal mushrooms. A high amount of essential free amino acids such as tryptophan, cysteine and methionine was determined in all investigated mushrooms although some of them showed a low content of protein. Aspartic and glutamic acids are the major amino acids in all investigated mushrooms. Among investigated mushrooms, the L. sulphureus was very good source of free amino acids.

F.pinicola and F. fometarus are woody, they contain high cellulose (respectively $28 \%$ and $41 \%$ ) and lignin (respectively $4 \%$ and $5 \%$ ). The mushroom F. officinalis contains a resin $70 \%$ of dry mass. A high amount (39\%) of extractible by water in I. obliquus.

The oil content of investigated mushrooms was in a range $1.5-3.5 \%$. Total unsaturated fatty acids were $88.76-98.72 \%$. Oleic $(\mathrm{C} 18: 1)$ and linoleic acid $(\mathrm{C} 18: 2)$ were the most represented fatty acids. Arachidonic acid (C20:4) were presented at 0.32-1.06\%. Therefore, all 5 mushroom's oils are physiologically active. The oil of F. fomentarus is a rich source of sterols and the oil of F. officinalis contains a manool, which is biologically active diterpenoid.

Investigated 4 mushrooms (F.officinalis, F.fomentarus, I.obliquus, L.sulphureus) contain good amounts (3.22-10.31\%) of minerals. The mushroom $F$. officinalis is very rich source of minerals.
\end{abstract}

